\title{
Education Level and Income Disparities: Implications for Financial Inclusion through Mobile Money Adoption in South Africa
}

\author{
Charles Nyoka \\ Ph.D.; Senior Lecturer; Department of Finance Risk Management and Banking \\ University of South Africa, Pretoria, South Africa \\ e-mail:nyokac@unisa.ac.za or charlesnyoka@yahoo.co.uk
}

\begin{abstract}
Financial inclusion has recently become an issue of concern the world over for governments, policymakers, non-governmental organizations (NGOs), and financial and non-financial institutions alike. McKinnon (1973) and Shaw (1973), in seminal presentations, brought the world's attention to the importance of an effective financial system for economic development.

In recent years, there has been growing theoretical and empirical works showing the strong linkages between financial development with economic growth and poverty alleviation.

After conducting statistical analysis using Stata version 14 for Windows with a multivariate binary logistic regression modeling technique applied, this paper tested and concluded that there is a statically significant relationship between educational levels on the one-hand and income levels on the other on the probability of one having a mobile banking account in South Africa. From a policy perspective, this information will assist policymakers in making more informed decisions with respect to education, and from the banking fraternity point of view it will help, them in the developments of products that are more in line with the population's education and income levels.
\end{abstract}

Keywords: financial inclusion, level of education, level of income, mobile banking

JEL: G21, N3, N27 


\section{Introduction}

Financial inclusion has recently become an issue of concern the world over for governments, policymakers, non-governmental organizations (NGOs), and financial and non-financial institutions (Quaye et al. 2014).

According to UNDESA and UNCDF (2006), the concept of financial inclusion encompasses two primary dimensions: (1) that financial inclusion refers to a customer having access to a range of formal financial services, from simple credit and savings services to more complex ones such as insurance and pensions; and (2) that financial inclusion implies that customers have access to more than one financial services provider, which ensures a variety of competitive options. Understanding and identifying the factors which affect the level of financial inclusion is important to policymakers and the academic field as well.

Research on issues regarding economic growth was pioneered by early economic theorists, who focused on shortages of real factors such as land and capital (e.g., machinery), but not the finance and financial markets as being constraints on economic growth. In the early 1990s, theorists like Schumpeter (1991) brought to the fore the importance of financial intermediary services for innovation and economic growth.

McKinnon (1973) and Shaw (1973), in seminal presentations, brought the world's attention to the importance of an effective financial system for economic development.

In recent years, there has been growing theoretical and empirical works showing the strong linkages between financial development with economic growth and poverty alleviation. Banerjee and Newman (1993) reported on the critical role that access to finance played in enabling people to exit poverty by enhancing productivity. Binswanger and Khandker (1995) and Eastwood and Kohli (1999) investigated the impact of Indian's rural banks' expansion program and found that rural poverty reduced and non-agricultural employment increased.

Burgess and Pande (2005) also echoed a similar positive impact on poverty reduction because of the bank branching regulations of India (between the 1970s and the 1990s) which required banks to open four branches in unbanked locations for every new branch opened in an urban area.

The study provides direct evidence that this expansion of the bank branch network had a positive impact on financial inclusion and, thereby, it led to a considerable decline in rural poverty (World Bank 2014).

Beck et al. (2009) showed how well developed financial markets and accessible financial services all reduce information and transaction costs, and influence savings rates, investment decisions, technological innovations, and long-run growth rates. According to Frost and Sullivan (2009), banking services are being viewed increasingly as a public good that needs to be made available to the entire population without discrimination.

It is against this background that this study seeks to examine the impact of income levels and education level on financial inclusion with respect to mobile banking and other modern financial instruments and gadgets. 
In the context of South Africa, with its history of apartheid, an understanding of the causes of financial exclusion on both its economy and population is merited.

\section{Literature review}

The current drive towards financial inclusion is an initiative that started 20 to 30 years ago (Asian Development Bank Institute 2014; Consultative Group to Assist the Poor (CGAP) 2010; Demirgüç-Kunt and Klapper 2012a). Patel and Graham (2012) maintain that South Africa has a long history of economic exclusion of the majority of the population through colonialism and apartheid. Preisendoerfer, Bitz, and Bezuidenhout (2014) argued that the black population of South Africa has a low participation rate in entrepreneurial activities and a low level of entrepreneurial ambitions due to the apartheid regime. The challenges of access to finance and poor knowledge of available formal financial institutions minimized the rate of black-owned small business to participate in the formal sector (Cant, Erdis and Sephapo 2014).

Gertler and Rose (1991) argue that economic growth and financial sector development are mutually dependent. Other authors have emphasized that financial sector policy can affect the pace of economic development. King and Levine (1993) empirically investigated the dynamic link between financial innovation and economic development. They argue that financial institutions lower the social cost of investing in intangible capital through the evaluation, monitoring, and provision of financing services. Montiel (1994) also noted that economic growth could be spurred by innovation in financial development that improves the efficiency of intermediation, thereby increasing the marginal product of capital and raising the savings rate. Levine et al. (2000) found that the exogenous components of financial intermediary development were positively associated with economic growth.

In the context of South Africa, the inability of black-owned businesses to access finance has an impact on the economic growth of the country as the black population accounts for $90 \%$ in the small and medium enterprise (SME) sector compared to the larger sector (SEDA 2017). The OECD (2015) states that it is primarily the responsibility of governments the world over to ensure that small enterprises do well, as governments carry the burden of assessing the extent of small enterprises financing needs and eliminating the gaps with relevant stakeholders, such as banks and financial institutions. According to Freeman (2008), one of the main issues that remain of concern is that the apartheid government used legislation as one of its main tools to provide white South Africans with abundant resources and economic opportunities. In spite of the racist division of resources in pre- and post-apartheid South Africa, the country's economy and societal well-being have been drastically affected by the lack of access to finance by most black-owned small businesses.

A number of factors can be attributed to this demise, among them, education levels and income disparities, which are the subject of examination in this paper. 
Kira and He (2012) agree that the main challenge preventing the small enterprise sector from contributing fully to economic growth is a lack of finance. Quaye, Abrokwah, Sarbah, and Osei (2014) share the same view as the researchers of a study in Ghana, who found that most small enterprises who were denied access to credit by commercial banks and other financial institution collapsed within the first three years of coming to being.

There is a great deal of literature linked to the subject of access to finance, especially in the small enterprise space. Beyers and Ndou's (2016) study addressed two main issues relating to the growth and development of small enterprises in South Africa, that is, the lack of financial management skills and lack of access to finance.

Kasseeah and Thoplan (2012) argue that the growth of small enterprises is a vital source of wealth creation for both the economy and the individual. It is implied, therefore, that denying someone access to financial resources for whatever reason is tantamount to denying both the economy and the individual access to wealth. Since banks, which spur economic growth and affect economic transformation, are key institutions in any economy (Djoumessi 2009), exploiting the advantages brought by information and communication technologies (ICT) is critical for economic development in the future. However, due to the challenges emanating from resistance to change, lack of information for consumers, and poor levels of education and income by those that are supposed to partake in new technologies, financial inclusion may remain a pipe dream for most African economies. Other common causes of financial exclusion (price or non-price barriers) cited in the literature include "geography (limiting physical access), regulations (lack of formal identification proof or of appropriate products for poor households), psychology (fear of financial institution's staff, structures, complicated financial products, etc.), information (lack of knowledge regarding products and procedures), and low financial acumen (low income and poor financial discipline), among others" (Ramji 2009; Demirgüç-Kunt and Klapper 2012a).

Demirgüç-Kunt et al. (2012b) observed that without inclusive financial systems, poor people have to rely on their own limited savings to invest in their education or become entrepreneurs, and small enterprises must rely on their limited earnings to pursue promising growth opportunities.

The available literature suggests that retail banks are facing huge challenges in migrating customers from the traditional ways of conducting business to take part in modern ways of conducting business (Singh 2004, p. 188; Brown and Molla 2005). Research conducted concluded that differences in attitude might exist between customers in different demographic groups. However, demographic factors alone are insufficient predictors of a customer's attitude. Financial inclusion must thus be treated like any public good due to its importance to both individual and economic development. The degree of 'publicness' in financial inclusion may be different from a typical public good like 'policing'

According to Creane et al. (2004), a robust financial system contributes to the economic and overall functioning of the national economy through promoting invest- 
ment and funding good business opportunities, mobilizing savings, and enabling the trading, hedging, and diversification of risk. This, in turn, results in a more efficient allocation of resources, more rapid accumulation of physical and human capital, and faster technological progress, and finally, it feeds into economic growth. Honohan and Beck (2007), among others, have shown that well-functioning, healthy and competitive financial systems are an effective tool in creating opportunities and fighting poverty by providing people with a wide range of financial services, such as savings, credit, payment, and risk management services.

In various studies, it has been observed that the absence of inclusive financial systems contributes to persistent income inequality and slower economic growth (Demirguc-Kunt and Levine 2009; Kempson 2006).

\section{Problem statement and research objectives}

In a bid to foster financial inclusion from a policy perspective, the South African government introduced a number of acts, among which is the National Credit Act (NCA); among other rights, it enforces the right to credit by all citizens. The government went on to introduce the Mzanzi account, an account with conditions for a minimum balance and on which no charges are to be levied.

All these happened in the midst of the rapid introduction of technology by banks. In the process, the government seems to have underplayed the importance and impact of levels of both education and income on financial inclusion.

The FinMark Trust (2016) indicates that in the Southern African Development Community (SADC) region, mobile money ownership remains low among low-income groups and people with either no education or low levels of financial literacy because of lower education levels. It is in light of the above that this paper explores the implications of education level and income disparities on financial inclusion through mobile money adoption in South Africa.

\section{Research questions and hypothesis}

The paper seeks to answer the questions of the effect that education levels and income disparities have on financial inclusion through mobile money adoption in South Africa. The research hypotheses developed as a result are that:

- Education levels disparities have statistically significant and disproportionate effects on financial inclusion through mobile money adoption in South Africa.

- Income disparities have statistically significant and disproportionate effects on financial inclusion through mobile money adoption in South Africa. 


\section{Contribution of the study}

This research study provides insights into the lack of financial inclusion through mobile money adoption in South Africa with respect to the existence of disparities in education and income levels among the country's population. It is also hoped that the research results may result in a policy shift by governments and financial sector players alike towards more consumer-friendly policies and financial products if the dream of financial inclusion is to be realized at all.

\section{Methodology and analytical technique}

\section{Data description}

The research used data from The World Bank (WB) Microdata 2014 Financial Inclusion Survey. The data was sourced from the World Bank Microdata Library online data portal. From the total 1000 participants surveyed, 995 were valid responses relevant to this research study, yielding a $99.5 \%$ effective response rate. Mobile money account ownership status was the binary response variable (no $=0$; and yes $=1$ ), while education level and income quintile were the covariates. Education level had three categories in the model (completed primary or less $=1$; secondary $=2$; and completed tertiary or more $=3$ ). Income quintile had five categories, namely poorest $20 \%=1$; second $20 \%=2$; middle $20 \%=3$; fourth $20 \%=4$; and richest $20 \%=5$.

\section{Estimation technique}

Statistical analysis was conducted using Stata version 14 for Windows. A multivariate binary logistic regression modeling technique was applied to estimate odds ratios with $95 \%$ confidence intervals based on the function specified below:

$$
\begin{aligned}
ð= & \operatorname{Pr}\left(\mathrm{Y}_{\mathrm{i}}=1 \mid \mathrm{X}_{\mathrm{i}}=\mathrm{x}_{\mathrm{i}}\right)=\frac{\exp \left(\alpha_{0}+\alpha_{1} \mathrm{x}_{\mathrm{i}}\right)}{1+\exp \left(\alpha_{0}+\alpha_{1} \mathrm{x}_{\mathrm{i}}\right)} \\
& \Rightarrow \operatorname{logit}\left(\pi_{\mathrm{i}}\right)=\log \left(\frac{\pi_{\mathrm{i}}}{1-\pi_{\mathrm{i}}}\right)=\alpha_{0}+\alpha_{1} \mathrm{x}_{\mathrm{i}}
\end{aligned}
$$

where: $Y$ represents the binary response variable (such that $Y_{i}=1$ signifies the presence of mobile money account ownership, and $Y_{i}=0$ describes the absence of mobile money account ownership), and $\mathrm{X}_{\mathrm{i}}$ represents a vector of a set of exploratory variables which include the education level and income quintile.

To determine the proportion of overall variation in mobile money account ownership status that was accounted for by education level and income quintile, the Cox 
$\&$ Snell Pseudo R-square and the Nagelkerke R-square were calculated. The respective test statistics were performed based on the functions specified below:

$$
\text { Cox \& Snell Pseudo } \mathrm{R}^{2}=1-\left(\frac{-2 \mathrm{LL}_{\mathrm{null}}}{-2 \mathrm{LL}_{\mathrm{k}}}\right)^{\frac{2}{\mathrm{n}}}
$$

Nagelkerke $\mathrm{R}^{2}$ (which divides Cox \& Snell $\mathrm{R}^{2}$ by its maximum) $=$

$$
=1-\frac{\left(\frac{-2 \mathrm{LL}_{\text {null }}}{-2 \mathrm{LL}_{\mathrm{k}}}\right)^{\frac{2}{\mathrm{n}}}}{1-\left(-2 \mathrm{LL}_{\text {null }}\right)^{\frac{2}{\mathrm{n}}}}
$$

where: $-2 L_{\text {null }}$ symbolizes the likelihood for the model with only an intercept; and $-2 \mathrm{LL}_{\mathrm{k}}$ represents the model with the predictor.

To examine the predictive power of the model, the area under the nonparametric Receiver Operating Characteristic (ROC) curve was computed. The respective curve, which is a graph of sensitivity versus 1 minus specificity, was derived at $c=0.5$ probability cutoff. Sensitivity refers to the fraction of observed positive outcome cases that are correctly classified, and specificity is the fraction of observed negative outcome cases that are correctly classified in the analytical process.

\section{Results and analysis}

This section presents summary statistics on the demographic profiles of the participants and the mobile money account ownership status according to education level and income quintile. The cross-tabulated frequencies and estimated odds results of mobile money account ownership status for each education level group and income quintile group were provided.

Table 1 above shows that from the total of 995 respondents surveyed, approximately $18 \%(n=183)$ reported they owned mobile money accounts, while $82 \%(n=812)$ of respondents reported that they did not have mobile money accounts. From the $18 \%$ ( $n=183)$ who had mobile money accounts, only $1 \%(n=13)$ had completed primary education or less, $12 \%(n=117)$ had completed secondary education, and $5 \%(n=183)$ had completed tertiary education or more.

The cross tabulation results presented in Table 2 above show that from the total of 995 respondents surveyed, approximately 18\% $(n=183)$ reported that they owned mobile money accounts, while $82 \%(n=812)$ of respondents reported that they did not have mobile money accounts. From the $18 \%(\mathrm{n}=183)$ who had mobile money accounts, $1 \%(n=14)$ were in the poorest $20 \%$ income quintile category, $2 \%(n=17)$ were 
in the second $20 \%$ income quintile category, $3 \%(n=25)$ were in the middle $20 \%$ income quintile category, $4 \%(n=36)$ were in the fourth $20 \%$ income quintile category, and $9 \%(n=91)$ were in the richest $20 \%$ income quintile category.

Table 1. Respondent education level * Has a mobile money account

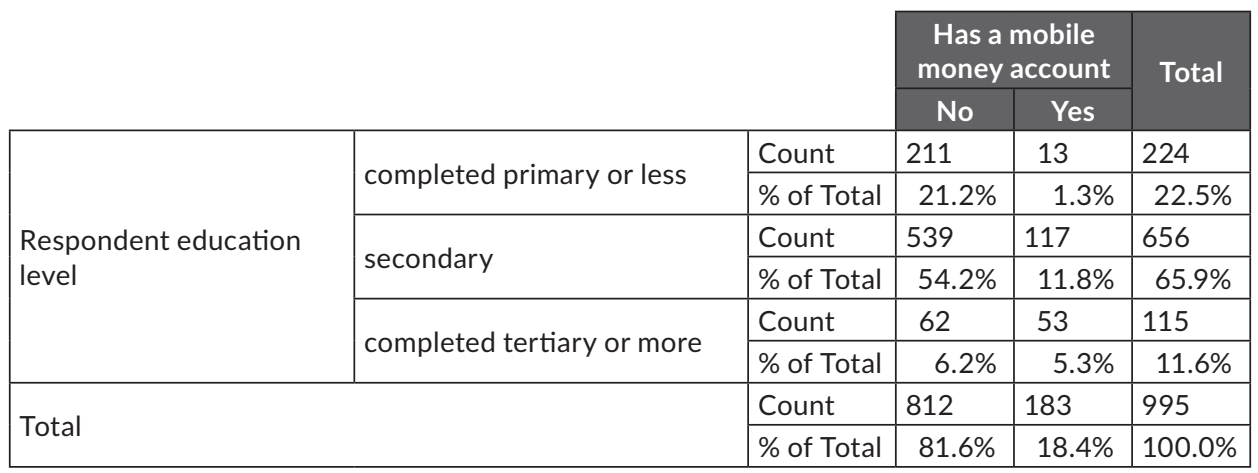

Source: own elaboration.

Table 2. Within-economy household income quintile * Has a mobile money account

\begin{tabular}{|c|c|c|c|c|c|}
\hline & & & \multicolumn{2}{|c|}{$\begin{array}{l}\text { Has a mobile } \\
\text { money account }\end{array}$} & \multirow[t]{2}{*}{ Total } \\
\hline & & & No & Yes & \\
\hline \multirow{10}{*}{$\begin{array}{l}\text { Within-economy } \\
\text { household income } \\
\text { quintile }\end{array}$} & \multirow{2}{*}{1 poorest $20 \%$} & \begin{tabular}{|l|} 
Count \\
\end{tabular} & 151 & 14 & 165 \\
\hline & & $\%$ of Total & $15.2 \%$ & $1.4 \%$ & $16.6 \%$ \\
\hline & \multirow{2}{*}{2 second $20 \%$} & Count & 172 & 17 & 189 \\
\hline & & $\%$ of Total & $17.3 \%$ & $1.7 \%$ & $19.0 \%$ \\
\hline & \multirow{2}{*}{3 middle $20 \%$} & Count & 144 & 25 & 169 \\
\hline & & $\%$ of Total & $14.5 \%$ & $2.5 \%$ & $17.0 \%$ \\
\hline & \multirow{2}{*}{4 fourth $20 \%$} & Count & 169 & 36 & 205 \\
\hline & & $\%$ of Total & $17.0 \%$ & $3.6 \%$ & $20.6 \%$ \\
\hline & \multirow{2}{*}{5 richest $20 \%$} & Count & 176 & 91 & 267 \\
\hline & & $\%$ of Total & $17.7 \%$ & $9.1 \%$ & $26.8 \%$ \\
\hline \multirow{2}{*}{\multicolumn{2}{|c|}{ Total }} & Count & 812 & 183 & 995 \\
\hline & & $\%$ of Total & $81.6 \%$ & $18.4 \%$ & $100.0 \%$ \\
\hline
\end{tabular}

Source: own elaboration.

The odds ratios (Table 3) are all statistically significant at the 5\% level and lie within the respective $95 \%$ confidence intervals. The results indicate that respondents who completed tertiary education or more had approximately eight times the odds of having a mobile money account than respondents with primary education or less. Similarly, respondents who completed secondary education had approximately three times the odds of having a mobile money account than respondents with primary education or less. Concerning the within-economy income quintile, respondents who are 
in the second and middle $20 \%$ income quintiles had approximately the same odds of not having mobile money account ownership based on the statistically insignificant z-statistics.

Table 3. Odds ratios for mobile money account ownership

\begin{tabular}{|c|c|c|c|c|c|c|}
\hline \multirow{3}{*}{\multicolumn{5}{|c|}{ Logis ic regression }} & \multicolumn{2}{|c|}{ No. of obs $=995$} \\
\hline & & & & & \multicolumn{2}{|c|}{$\operatorname{LR} \operatorname{chi} 2(3)=86.94$} \\
\hline & & & & & \multicolumn{2}{|c|}{ Prob $>$ chi $^{2}=0.000$} \\
\hline \multicolumn{5}{|c|}{ Log likelihood = -32704.664 } & \multicolumn{2}{|c|}{ Pseudo $\mathrm{R}^{2}=0.110$} \\
\hline $\begin{array}{l}\text { Mobile money } \\
\text { ownership }\end{array}$ & Odds Ratio & Robust S.E. & Z & $\mathrm{P}>|z|$ & \multicolumn{2}{|c|}{ [95\% Conf. Interval] } \\
\hline \multicolumn{7}{|c|}{ Education levela $^{\mathrm{a}}$} \\
\hline Secondary & 2.805 & 0.862 & 3.36 & 0.000 & 1.536 & 5.124 \\
\hline Tertiary or more & 8.00 & 2.853 & 5.84 & 0.000 & 3.982 & 16.102 \\
\hline \multicolumn{7}{|c|}{ Income quintile ${ }^{b}$} \\
\hline Second $20 \%$ & 1.040 & 0.404 & 0.10 & 0.918 & 0.486 & 2.227 \\
\hline Middle $20 \%$ & 1.737 & 0.623 & 1.54 & 0.124 & 0.859 & 3.510 \\
\hline $\begin{array}{l}\text { Fourth } 20 \% \\
\text { Richest 20\% } \\
\text { _cons }\end{array}$ & $\begin{array}{l}1.995 \\
3.500 \\
0.039\end{array}$ & $\begin{array}{l}0.684 \\
1.121 \\
0.015\end{array}$ & $\begin{array}{r}2.01 \\
3.91 \\
-8.14\end{array}$ & $\begin{array}{l}0.044 \\
0.000 \\
0.000\end{array}$ & $\begin{array}{l}1.018 \\
1.867 \\
0.184\end{array}$ & $\begin{array}{l}3.907 \\
6.558 \\
0.086\end{array}$ \\
\hline
\end{tabular}

a The primary education or less group was used as the reference category for education level

b The poorest 20\% group was used as the reference category for the within-economy household income level

Source: own elaboration.

The respondents who are in the fourth $20 \%$ quintile had approximately twice the odds of having a mobile money account than respondents with primary education or less. Similarly, respondents who are in the fourth $20 \%$ quintile had about three times the odds of having a mobile money account than respondents with primary education or less. The LR test statistic indicates the significance of the full model with a predictor; while the Pseudo $\mathrm{R}^{2}$ indicates about $11 \%$. Variation in mobile money account ownership was accounted for by education level and the within-economy income quintiles.

The results regarding model sensitivity indicate that $21.86 \%$ of respondents with mobile money account were correctly classified. Similarly, the results regarding specificity indicate that $95.57 \%$ of respondents surveyed with no mobile money account were correctly classified. Technically, the model yielded the predicted $\mathrm{p}=0.05$ for $995 \mathrm{re}$ spondents, from which 40 respondents (positive predicted value $=52.63 \%(40 / 76)$ ) had a mobile money account. Proceeding further, the model predicted that out of the 812 surveyed respondents, 776 of them (predicted negative value $=84.44 \%$ ) did not have a mobile money account. Overall, the model's correct classification rate was $82.01 \%$, with $98.09 \%$ of the respondents who did not have a mobile money account correctly classified but only $21.86 \%$ of the group with a mobile money account correctly classified. 
Table 4. Classification summary statistics for the model

\begin{tabular}{|c|c|c|c|}
\hline \multirow{2}{*}{ Classified } & \multicolumn{2}{|c|}{ True } & \multirow{2}{*}{ Total } \\
\hline & D & $\sim \mathrm{D}$ & \\
\hline+ & 40 & 36 & 76 \\
\hline- & 143 & 776 & 919 \\
\hline Total & 183 & 812 & 995 \\
\hline \multicolumn{4}{|c|}{ Classified + if predicted $\operatorname{Pr}(D)>=0.5$} \\
\hline \multicolumn{4}{|c|}{ True D defined as mobile money account ownership !=0 } \\
\hline Sensitivity & & $\operatorname{Pr}(+I D)$ & $21.86 \%$ \\
\hline Specificity & & $\operatorname{Pr}(-I \sim D)$ & $95.57 \%$ \\
\hline Positive predictive value & & $\operatorname{Pr}(\mathrm{DI}+)$ & $52.63 \%$ \\
\hline Negative predictive value & & $\operatorname{Pr}(\sim \mathrm{DI}-)$ & $84.44 \%$ \\
\hline Correctly classified & & & $82.01 \%$ \\
\hline
\end{tabular}

Source: own elaboration.

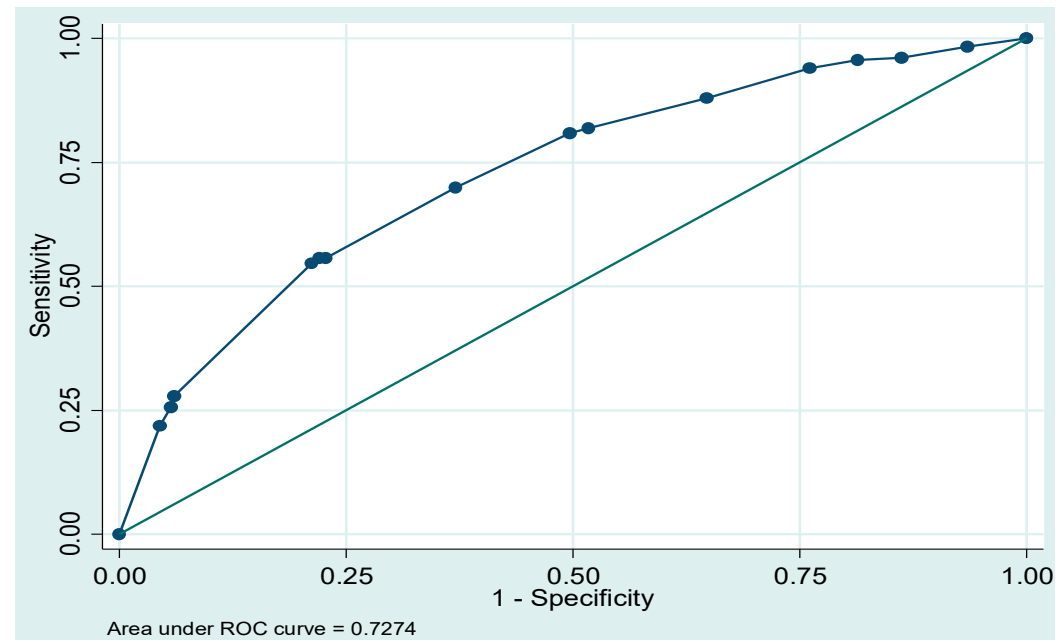

Figure 1. Area under the Receiver Operating Characteristic (ROC) curve $^{a}$

Null hypothesis: true area $=0.5$

Source: own elaboration.

To examine the predictive power of the model, the area under the ROC curve was statistically calculated. Given that a model with no predictive power would be a $45^{\circ}$ line with an area $=0.5$, the estimated area $(=0.727)$ under the curve indicates that the model indeed had some predictive estimation power. 


\section{Conclusions}

The results of the study confirm the existence of a relationship between the level of education on the one hand and the level of income on the other. The results show that the higher the education level, the greater the odds for one to have a mobile account. The results also show that the higher the income level, the greater the odds of one having a mobile banking account.

In the context of South Africa, a country that experienced Bantu education over a very long period, it is imperative for the government of that country to prioritize basic education to enhance literacy levels that may trigger an increase in the use of mobile banking devices. The results of the study are useful to both governments and financial institutions as far as financial inclusion is concerned.

The government of South Africa has an obligation to bring its population up to speed on the usage of mobile devices. This can be achieved through a variety of strategies and policy positions, among which may be the adoption of local languages in the marketing process of these banking devices

Overall, from a government policy perspective, this information will assist policymakers in making more informed decisions with respect to education, and from the banking fraternity point of view, it will help them in the development of products that are more suited to the population's education and income levels.

\section{References}

Banerjee, A.V. and Newman, A.F. (1993), Occupational choice and the process of development, "The Journal of Political Economy”, 101 (2), pp. 274-298.

Beck, T., Demirguc-Kunt, A. and Honahan, P. (2009), Access to Financial Services: Measurement, Impact, and Policies, The World Bank Research Observer Advance Access, Oxford University Press.

Beyers, L.J.E. and Ndou, P.M. (2016), The Dichotomy between Small, Medium and Micro Enterprises and Financial Institutions in Thohoyandou, "Journal of Economics", 7 (1), pp. 31-37.

Binswanger, H.P., Khandker, S.R. (1995), The impact of formal finance on the rural economy of India, "Journal of Development Studies", 32 (2), pp. 234-265.

Brown, I. and Molla, A. (2005), Determinants of Internet and cell phone banking adoption in South Africa, "Journal of Internet Banking and Commerce", 9 (4), pp. 1-9.

Cant, M.C., Erdis, C. and Sephapo, C.M. (2014), Business survival: the constraints experienced by South African SMEs in the financial sector, "International Journal of Academic Research in Business and Social Sciences”, 4 (10).

CGAP (Consultative Group to Assist the Poor) (2009), Financial Access 2009: Measuring Access to Financial Services around the World, Washington, DC: CGAP, World Bank. 
CGAP (2010), Innovative Financial Inclusion, Principle and Report on Innovative Financial Inclusion from the Access through Inclusion Sub-Group of the G20 Financial Inclusion Expert Group, May 25.

Creane, S., Rishigoyal, A., Mushfiqmobar, A.K. and Randas, A.B. (2004), Financial Sector Development in the Middle East and North Africa, IMF Working Paper 04/201, Washington, D.C.

Demirguc-Kunt, A., and Klapper, L. (2012a), Measuring Financial Inclusion: The Global Findex Database, Policy Research Working Paper 6025, World Bank, Washington, DC.

Demirguc-Kunt, A. and Klapper, L. (2012b), Financial Inclusion in Africa: An Overview, Policy Research Working Paper No. 6088, World Bank, Washington D.C.

Demirguc-Kunt, A. and Levine, R. (2009), Finance and Inequality: Theory and Evidence, "Annual Review of Financial Economics", 1, pp. 287-318.

Djoumessi, E.C. (2009), Financial development and economic growth: a Comparative study between Cameroon and South Africa, Submitted in fulfillment of the requirements for the degree of master of commerce (PDF) Financial sector development and economic growth: evidence from Cameroon. Available from: https://www.researchgate.net/publication/320915378_Financial_sector_development_and_economic_growth_evidence_from_Cameroon (accessed: 9.10.2018).

Eastwood, R., and Kohli, R. (1999), Directed credit and investment in small-scale industry in India: Evidence from firm-level data, 1965-1978, "Journal of Development Studies", 35 (4).

Freeman, A. (2008), Community Reinvestment Legislation and Access to Housing Finance in Post-Apartheid South Africa, "Housing Studies", 23 (5), pp. 697-716.

Finmark Trust Annual Report 2016, https://finmark.org.za/annual-report-2016/ (accessed: 20.04.2019)

Frost and Suvillian, NCR, (2009), Bringing Financial Services to The Masses, Dayton, Ohio.

Gertler, M.*Rose, Thomas, A., (1991), Finance, growth, and public policy, Policy Research Working Paper Series 814, The World Bank.

Honohan, P. and Beck, T. (2007), Making Finance Work for Africa, World Bank, Washington D.C.

Kasseeah, H. and Thoplan, R. (2012), Access to Financing in a Small Island Economy: Evidence from Mauritius, "Journal of African Business", 13 (3), pp. 221-231.

Kempson, E. (2006), Policy level response to financial exclusion in developed economies: lessons for developing countries, Paper for Access to Finance: Building Inclusive Financial Systems, May 30-31, 2006, World Bank, Washington, D.C.

King, R.G. and Levine, R. (1993), Finance and growth: Schumpeter might be right, "Quarterly Journal of Economics", 108 (3), pp. 717-737.

Kira, A.R. and He, Z. (2012), The impact of firm characteristics in access of financing by small and medium-sized enterprises in Tanzania, "International Journal of Business and Management", 7 (24), pp. 108-119.

Levine, R., Loayza, N. and Beck, T. (2000), Financial intermediation and growth: Causality and causes, "Journal of Monetary Economics", 46, pp. 31-77. 
McKinnon, R.I. (1973), Money and Capital in Economic Development, Washington, DC: Brookings Institution.

Montiel, P. (1994), Financial Policies and Economic Growth: Theory, Evidence and Country specific Experience from sub-Saharan Africa. Paper presented at the African Economic Research Consortium biannual workshop, Nairobi, May 1994.

OECD (2015), Progress report on G20/OECD High-level principles on SME financing, OECD report to G20 finance minister and central banks Governors, September, OECD Paris. Available at https:/www.oecd.org/finance/private-pensions/ G20-OECD-High-level-Principles-on-SME-Financing-Progress-Report.pdf (accessed: 20.04.2019).

Patel, L. and Graham, L. (2012), How broad-based is broad-based black economic empowerment?, Development Southern Africa, 29 (2), pp. 193-207.

Preisendoerfer, P., Bitz, A., and Bezuidenhout, F.J. (2014), Black entrepreneurship: a case study on entrepreneurial activities and ambitions in a South African township, "Journal of Enterprising Communities: People and Places in the Global Economy”, 8 (3), pp. 162-179.

Quaye, I., Abrokwah, E., Sarbah, A. and Osei, J.Y. (2014), Bridging the SME Financing Gap in Ghana: The Role of Microfinance Institutions, "Open Journal of Business and Management", 2, pp. 339-353.

Ramji, M. (2009), Financial Inclusion in Gulbarga: Finding Usage in Access. Working Paper.

Runzhong, P., Min, Z, and Lei, W. (2014), Financial Inclusion in the People's Republic of China: Achievements and Challenges, Asian Development Bank Institute, Financial Inclusion in Asia: Country Surveys, Asian Development Bank Institute, Japan, pp. 7-44.

Schumpeter, Joseph A. (1911), The Theory of Economic Development, Cambridge, MA: Harvard University Press, US.

SEDA (2017), The small, medium and micro enterprise sector of South Africa. Available at http://www.seda.org.za/Publications/Pages/SmallBusinessPublications.aspx. (accessed: 8.10.2017).

Singh, B. and Malhotra, P. (2004), Adoption of the internet banking: An empirical investigation of Indian banking sector, "Journal of Internet Banking and Commerce", $9(2)$.

The World Bank (2014), Global Financial Development Report 2014: Financial Inclusion, Washington, DC: World Bank. Doi: 10.1596/978-0-8213-9985-9. License: Creative Commons Attribution CC BY 3.0.

UNDESA and UNCDF (2006), Building Inclusive Financial Sectors for Development, United Nations: New York.

World Bank Micro-Data (2016), http://microdata.worldbank.org/ (accessed: 20.04.2019)

World Economic Forum (2011), The Mobile Financial Services Development Report, Geneva. 


\section{Streszczenie}

\section{Poziom wykształcenia i różnice dochodowe: implikacje dla włączenia finansowego związanego z wprowadzeniem pieniądza mobilnego w Afryce Południowej}

Problem włączenia finansowego stał się w ostatnim czasie przedmiotem troski zarówno rządów, decydentów, organizacji pozarządowych (NGO), jak również instytucji finansowych i niefinansowych na całym świecie. McKinnon (1973) i Shaw (1973) w swoich najważniejszych pracach zwrócili uwagę świata na znaczenie efektywnego systemu finansowego dla rozwoju gospodarczego.

W ostatnich latach coraz więcej prac teoretycznych i empirycznych wskazuje na silne związki między rozwojem finansowym a wzrostem gospodarczym i ograniczaniem ubóstwa.

Po przeprowadzeniu analizy statystycznej przy użyciu programu Stata w wersji 14 dla systemu Windows z zastosowaniem modelowania wieloczynnikowej binarnej regresji logistycznej (multivariate binary logistic regression modeling), w niniejszym artykule wykazano, że istnieje statystycznie istotny związek między poziomem wykształcenia z jednej strony i poziomem dochodów z drugiej strony, a prawdopodobieństwem posiadania konta bankowości mobilnej przez mieszkańców Afryki Południowej. Z punktu widzenia prowadzenia polityki, informacje te mogą być przydatne decydentom w podejmowaniu bardziej świadomych decyzji dotyczących edukacji, a sektorowi bankowemu mogą pomóc w rozwijaniu produktów, które będą lepiej dostosowane do poziomu wykształcenia i poziomu dochodów ludności.

Słowa kluczowe: włączenie finansowe, poziom wykształcenia, poziom dochodów, bankowość mobilna 